Le déficit en cellules germinales est loin de suffire à expliquer, à lui seul, 1'arrêt de croissance des gonades. Le déficit en tissu somatique est plus important. La différence de volume entre les gonades des freemartins et des foetus témoins est due pour 95 p. cent à une déficience en tissu somatique chez les foetus de 49 à $59 \mathrm{j}$ et pour 70 p. cent environ chez les fotus de 60 à I ro j. Cependant, chez les freemartins de 49 à $59 \mathrm{j}$, le nombre des cellules germinales par unité de volume gonadique est identique à celui des témoins. Il y a donc proportionnalité entre la réduction du nombre des cellules germinales et la réduction du volume de tissu somatique; ceci ne s'observe plus après $59 \mathrm{j}$.

La méiose apparaît chez tous les freemartins de plus de $77 j$, mais à chaque stade, elle ne concerne qu'un petit nombre des cellules germinales présentes. De plus, elle ne semble pas évoluer au delà du stade pachytène. Après le stade où sont apparues les premières figures de méiose, le nombre des cellules germinales contenues dans les gonades diminue beaucoup, il en subsiste encore quelques-unes après i $50 \mathrm{j}$, mais aucune n'est en méiose.

\title{
Cytogenetic and Reproductive studies of Bulls Born Co-Twin to Freemartins
}

\author{
H. O. DUNN, C. E. HALL and K. MCENTEE
}

N.Y.S. College of Veterinary Medicine, Cornell University, Ithaca N. Y. 14850, U.S.A.

Thirteen A.I. Center bulls, born twin to freemartins, were karyotyped. Records of reproductive performance were available on $\mathrm{I} 3$ and necropsy specimens on 8 . Fifty or more metaphases from cultured lymphocytes were scored to establish the XX/XY ratios. The percentage of XX cells, which ranged from $6 \mathrm{p}$. cent to $93 \mathrm{p}$. cent, were used to identify the bulls.

Five bulls ( $13 \mathrm{XX}, 36 \mathrm{XX}, 43 \mathrm{XX}, 60 \mathrm{XX}$, and $7 \mathrm{xXX}$ ) either failed to produce semen or the semen produced was below standards for sperm motility, concentration and morphology, and as young bulls they were culled. The highest percentage of abnormal sperm were observed in I 5 successive, unsatisfactory ejaculates of $60 \mathrm{XX}$.

The remaining eight bulls were used for artificial breeding. Four $6 \mathrm{XX}, 30 \mathrm{XX}, 63 \mathrm{XX}$, $84 \mathrm{XX})$ are now in-waiting for A.I. proofs. With the exception of $63 \mathrm{XX}$, which produced a high percentage of sperm with acrosomal defects, their sperm production and fertility as young bulls were satisfactory. Thirty-three p. cent of the frozen semen of the young bull $29 \mathrm{XX}$ was discarded, but freezability of his sperm appeared satisfactory as a 6-year-old when he was culled for A.I. production. Fertility of $33 \mathrm{XX}$ was below breed average. Two Holsteins, $85 \mathrm{XX}$ and $93 \mathrm{XX}$, were used as A.I. proven sires. Their sperm production as young bulls was below the average of their randomly chosen stablemates. There was a highly significant decline $(P<0.01)$ in $85 X X$ 's sperm production as a 6-year-old, and he was culled as an 8-year-old despite his good fertility record. Fertility of $93 \mathrm{XX}$ was slightly below breed average but semen samples were satisfactory until severe spondylosis at age ro complicated his semen collection.

The sex ratios of offspring of $29 \mathrm{XX}, 33 \mathrm{XX}$ and $85 \mathrm{XX}$ were obtained. A skewed male: female sex ratio of 29:7 $\mathrm{r}$ in offspring of $33 \mathrm{XX}$ was significant $(P<0.05)$. There was no evidence of germ cell chimerism based on blood typing of three offspring of $33 \mathrm{XX}$ and 23 offspring of $85 \mathrm{XX}$.

Necropsy specimens from ${ }_{13} \mathrm{XX}, 29 \mathrm{XX}, 36 \mathrm{XX}, 43 \mathrm{XX}, 60 \mathrm{XX}, 7 \mathrm{IXX}, 85 \mathrm{XX}$ and $93 \mathrm{XX}$ revealed various levels of testicular degeneration.

These results indicate that $\mathrm{XX} / \mathrm{XY}$ chimeric bulls are high risk sires for breeding purposes, probably as a result of hormonal deficiencies or invasion of the gonac ds with XX primordial germ cells.

\section{Le chimérisme $\mathrm{XX} / \mathrm{XY}$ ne joue pas de rôle dans la phase initiale du freemartinisme chez les bovins}

\author{
B. VIGIER, J. PREPIN, A. LOCATELLI, F. Du MESNIL du BUISSON et A. JOST \\ Physiologie Comparée, 9, quai St-Bernard, 75 Paris-5 ${ }^{\mathrm{e}}$, France
}

Le développement des anomalies sexuelles chez les foetus freemartins passe par deux phases successives distinctes: - entre 50 et $70 \mathrm{j}$, une phase initiale exclusivement d'inhibition (arrêt du développement de la gonade et régression des canaux de Müller comme chez les mâles) - après 